\title{
Local Government and Local Development: Bridging the Gap through Critical Discourse: Evidence from the Commonwealth Caribbean
}

\author{
Commonwealth Journal of Local Governance \\ Issue 10: December 2011- June 2012 \\ http://epress.lib.uts.edu.au/ojs/index.php/cjlg
}

\author{
Eris D Schoburgh \\ University of the West Indies \\ Mona Campus \\ Kingston
}

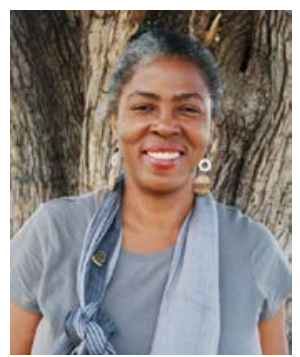

\begin{abstract}
Local development, whether construed broadly as community development or more narrowly as local as economic development (LED) is not always associated with local government but rather is the purview of a central government department or agency in Anglophone Caribbean policy systems. However with the emergence of 'local place - and people-oriented approaches' to development that offer new propositions about how to respond to risks and opportunities brought by globalization, local government is seen increasingly as an appropriate institutional context in which to pursue short-range objectives, such as creation of market opportunities and redressing the disparities within national economies; as well as the long-range goal of social transformation.
\end{abstract}

A developmental role for local government raises two questions that form the central concerns of this paper: What are the institutional and organisational imperatives of a developmental role for local government? To what extent have these imperatives been addressed in reform? A critical analysis of local government reform policies in Trinidad and Tobago and Jamaica revealed substantive convergence around local development as an outcome of reform but also important divergence in the approach to achieving this goal which suggests the absence of a cohesive model. The paper argues for a new agenda in reform that links local government more consistently with a local development strategy. It asserts that such a strategy must incorporate gender equality, the informal economy and institutional organisational capacity in the process of transformation and as a basis for creating a local context in which all types of resources can be maximized in the process of wealth creation in a locality.

\section{Introduction}

The debate about local development in the Commonwealth Caribbean is gathering momentum and much of it is being done against the institutional backdrop of local government. Two orientations are observed: In countries with well-established systems of local government the concern surrounds the exclusion of this level of government from the process of development generally; in countries that have undeveloped systems of local government pressure is being brought to bear on government to establish a viable 
subnational governmental framework to which responsibility for local development will be delegated.

In either case the pursuit of local development via the medium of local government has emerged as a priority. Victor Ayeni in the 2004 Report of the Commonwealth Local Government Forum (CLGF) noted that "(l)ocal government plays an essential role in the development process as it is the closest tier of government to ordinary citizens," a sentiment that seems to be in synchrony with 'local place and people-oriented approaches' to development that offer new propositions about how to respond to risks and opportunities brought by globalization. Local government is seen increasingly as an appropriate institutional context in which to pursue short-range objectives, such as creation of market opportunities and redressing the disparities within national economies; as well as the longrange goal of social transformation.

Acting on cue reformers in the Caribbean region have declared a symbiosis between local government and local development, with local economic development (LED) as an implicit but significant policy objective. In all of this there is a presumption of a new role for local government. Following Neville Duncan's advice to the Commonwealth Local Government Forum (CLGF) in 2004:

The single most important opportunity for local government is for it to develop a model for local development and systematically seek to implement it within the framework of national development strategies. This would considerably increase the role, position and importance of local governance within the national governance system (p. 60).

Duncan (2004) opines further that a developmental role for local government could have a transformative effect on the socio-political superstructure as local democracy would be strengthened and service delivery would be improved (Ibid).

However a developmental role for local government raises two questions that form the central concerns of this paper: What are the institutional and organisational imperatives of a developmental role for local government? To what extent have these imperatives been addressed in reform? A critical analysis of local government reform policies in Trinidad and Tobago ${ }^{1}$ and Jamaica revealed substantive convergence around local development as an outcome of reform but conversely important divergence in the approach to achieving this goal which suggests the absence of a cohesive model of local development.

\footnotetext{
${ }^{1}$ The constitution of the Republic of Trinidad and Tobago entrenches the Tobago House of Assembly (TBA) as a local government body with a degree of autonomy and the TBA Act of 1996 empowers it to formulate and implement policies on behalf of the jurisdiction.
} 
The analysis in this paper is developed throughout six sections with Sections 1-3 providing conceptual foundation of the major positions on local development to set the framework for an understanding of the new role envisaged for local government. Section 4 compares the reform process in Trinidad and Tobago and Jamaica. Sections 5 and 6 extrapolate the "model” of local development being pursued by engaging three propositions on which it depends, followed by a summary analysis and the conclusion.

\section{Defining 'Local Development'}

The first task is to establish the meaning of "local" to convey the interpretation local development used in this analysis, recognizing that though local development is distinguishable from community development or even local economic development (LED) the concepts are linked (see e.g. Porter 1990, 1995, 1998; Bingham and Mier 1993; Blair 1995; Plummer and Taylor 2001; Blakely and Bradshaw 2002).

Early theories of local development were not merely economic based but were preoccupied with place. For the most part these theories were macro in their outlook in that 'local' was used interchangeably with 'regional' with two primary connotations evolving around 'region'. Region at one time is depicted as a geographic space within multi-tiered countries such as Canada or the United States and to which is associated the concepts of 'growth centre (pole) and hinterland.' At other times region is interpreted in the context of intercountry comparisons of economic linkages particularly between developed and developing countries.

In this case a 'region' may be seen as a group of nations, such as the Caribbean or a single country, which finds expression in the concepts of 'core' (also centre) used in reference to the developed country and 'periphery' that describes the developing country. The leadinglaggard conception used to describe policy innovation and diffusion that may take place between developed regions or countries and their lesser developed counterparts is used to explain the economic differentials between locations.

Local development in this paper is interpreted within the geographic confines of the state. Thus 'local' is both spatial and locality-based, and is also endogenous in character meaning that the impetus for any form of initiative is found principally in the area in question (Coffey and Polese 1984). In terms of territoriality 'local' is understood to be subnational in scope but may manifest as regions, cities, districts or in less tangible forms as networks or temporary associations. 
Local development is therefore a process of socio-economic transformation that occurs due to the use of initiatives, application of skills of actors as well as efficient and effective utilization of all types of resources located within a subnational space. It is distinguishable from community development which incorporates similar values but is broader in scope. Community development may be seen as the pursuit of specific socio-economic objectives via local action and deployment and allocation of local resources in tandem with national goals. While exogenous factors cannot be ignored in the process of social transformation that is attached to local development or community development, the emphasis on endogenous factors assigns local government a special place in the process. And the concepts of leadinglaggard or growth centre-hinterland or core-periphery are relevant and useful socioeconomic characterization of regions, cities or districts within the state. Finally, local economic development is considered to be a critical lever of local or community development.

Suffice it to say that perhaps this paper errs on the side of simplicity given the never ending debate about what is development, complicated by the various qualifiers that emerge over time - local and community being just two. These are the meanings that will inform this analysis.

\section{Theorising Local Development Processes}

There is an abundance of explanations with varied assumptions about how local development occurs and each set of assumptions can be linked to an interpretation of 'local'. The two most relevant to this paper - leading-laggard and learning regions modules - are discussed here, to demonstrate that local development places specific demands on local political institutions to translate ideas into practice.

\section{Leading-laggard model}

The idea postulated in this discourse is that location is a critical determinant of the development potential of firms/industries. An important factor is the capacity of the site/locale to ensure the firm's competitiveness in the marketplace. Part of what enhances competitiveness is the firm's ability to incur minimal costs in linking raw materials to markets. The least cost variable is illustrated in the industrial site model of local development in which it is assumed that resources (raw materials) exist in a particular space in inert form and it is through the interventions of firms that their developmental values are realised. This is so because the distance between raw materials and markets is relatively short. Information and communication technologies (ICTs) have made distance less of a consideration in where to locate firms/industries but have not erased it totally. 
Following this line of argument urban centres are deemed suitable for supporting "large economic units" (firms) that are in turn viewed as "instruments of prosperity” (Perroux 1950: 103) given their ability to induce economic activity within their sphere of influence (Boudeville 1966: 11). These urban centres are conceived as "growth poles” (Perroux 1950) because they are endowed with knowledge and information and are able to support large firms that are "vehicles of dynamic change, fostering new technologies of production and organisation” (cited in Plummer and Taylor 2001: 223). The classic interpretation is that local development occurs because growth flows from industrial centres to lesscostly/peripheral locations. A counter argument is that growth poles are linked to other growth poles and not necessarily the periphery (Perroux 1950) suggesting that there is little spread effect of development in the absence of specific economic linkages.

However Gunnar Myrdal's (1957) theory of “cumulative causation” advances the location thesis by arguing that certain locations have a competitive advantage because they have markets that attract capital, skill and expertise. These locations are termed "leading regions". But the "lagging regions" may experience some backwash effects in the form of migration of skilled and educated workers and venture capital to "leading regions”. Myrdal (1957) propounds that the development differential between these economic spaces can be minimized through public policy which can be used to discourage certain kinds of investment in "leading regions" and induce investment in those that are "lagging”. Malizia and Feser (1999:103) make the point: "industrial growth can be diffused to backward regions by concentrating infrastructure investments and direct business investments at selected locations that possess growth potential.”

The differences in the growth prospects of locations are developed further in the "hierarchy of settlements" concept that distinguishes locations according to functions in the economic value chain. At the bottom of the hierarchy are the smallest areas that provide the narrowest range of services to residents. Social interactions in these locations are predominantly faceto-face and economies of scale are characteristically low. These small areas are markets for, and suppliers of resources (raw materials and industries) to intermediate levels that are described as "minimum convenience centres." The intermediate level in the hierarchy functions similarly for the urban centres at the top and in which are found all the activities at the lower levels in addition to other functions but with greater levels of specialization and productivity. Development occurs due to functional integration of these tiers of geographic areas. The hierarchy of settlement concept is used to explain why certain services are located in particular areas as well as the reason for economic decline in others (Howland 1993). 
The other side of the debate is that areas in economic decline can impact their economic fortunes positively by using incentives and subsidies to attract investment. The presumption is that localities have the capacity to determine how they are viewed by industrialists/investors. Thus localities are products within a marketplace of similar products and as such must be packaged to assure their competitive advantage to which investors will be drawn. Investments in these areas will "generate taxes and increase economic wealth" (Blakely and Bradshaw 2002:66) overtime reducing the locality’s reliance on subsidies.

New markets theory synthesises the foregoing ideas in its acknowledgment of the unrealised economic potential of, for example inner-city neighbourhoods that are economic opportunity zones. Carr (1999), intimates that the economic potential of the innercity lies inter alia, in understanding the value of their assets, developing and matching financing tools to these assets, and designing institutional arrangements that recapture value to recycle new wealth back into these communities (Blakely and Bradshaw 2002: 62). Porter's (1990:1998) concept of 'clustering' which describes the close proximity of inner-city neighbourhoods to large collections of related companies that are competitive nationally and internationally is used to elaborate the economic prospects of innercity neighbourhoods.

\section{Learning regions and innovative milieux}

Institutional, cultural and social factors are recognizably important considerations in local development (see, e.g., Kuznets (1965; 1966; Friedmann and Weaver 1979; Ostrom 1990, 1994, 2005; Clague 1997) and are theorized using the concepts of 'learning regions' and ‘innovative milieus’.

Learning regions according to Malmberg, Solvell and Zander (1996) are endowed with "a regional variety of skills and competencies, where the-often unplanned interaction between different actors will lead to new-often unexpected-ideas [i.e. synergies](88)”. Innovative milieus are subsections/areas of a geographic space much like a community or district in which may be found "certain coherence based on common behavioural practices" (Plummer and Taylor 2001: 226).

Plummer and Taylor (2001:226) identified four characteristics that distinguish these innovative milieus:

(a) a group of actors (firms and institutions) that possesses a degree of autonomy to make decisions and develop strategies;

(b) elements that are tangible, intangible and institutional that 
include firms, infrastructure, knowledge, know-how, authorities and legal frameworks;

(c) norms of cooperation in the interactions among actors; and

(d) self-regulation that induces learning.

Learning regions and innovative milieus are tools of institutional analyses used to show place-specific economic activity can be pursued and in which are assigned critical roles for information, (tacit) knowledge and ‘learning’ as stimulants for local development.

Learning regions and innovative milieus support the development of networks, based on shared cultural, psychological and political experiences that may offset immobility of capital that can affect local development. However strong psycho-social connection to a locality along with local integration of firm enhances the aforementioned features of innovative milieus and in turn fosters place-based learning, continuous innovation, and the constant refreshment and reinforcement of local competitive advantage” (Ibid 226).

\section{Assessment}

The explanatory power of the place-base theories discussed above has improved overtime with a marked shift in the focus of these models of local development from "attracting factories to attracting entrepreneurial populations, particularly certain socio-economic groups to a community or area” (Blakely and Bradshaw 2002: 66).

However, emphasis on growth does not sit well with broad-based conceptions of local development to which local government is linked; especially given its distributional problems (see e.g. Blair 1995). Yet growth is recognizably important as it points to critical economic indicators such as employment creation that are positively related to quality of life issues at the subnational level and with which local government ought to be concerned in its new role. While economics represents a critical dimension of local development there are socio-cultural and institutional elements that are relevant to the communitarian approach that is a fundamental raison d'être of local government within the current socio-economic environment.

A communitarian approach rides on certain assumptions:

- that the community is vested with good quality human resources in the form of requisite levels of creativity and talents, knowledge resources in the form of technical, scientific and market information to identify infrastructural resources with developmental values as well as gain access to capital resources; 
- that through communal bonds good social capital will be developed which will transform individual/personal utility into social/public utility; and

- that greater economies of scale will be achieved through community ownership of the process and structures set up to facilitate development.

The fact that local government reform in the Caribbean has evolved alternative models of local development, viz., regional vs. communitarian strategy, suggests that the fundamental concern of how to sustain growth and development at the local level has not been erased. Both strategies presume that there are certain self-generating capacities that are as, or even more important, than the traditional factors of production - labor and capital - which Coffey and Polese (1984) assert are “a population's entrepreneurial spirit and the sum of its knowledge and talents” (p. 3).

Implicit in the leading-laggard conception is the quality of the capacity of local government to deal with the development differentials between localities/areas. The hierarchy of settlements interpretation demands an appreciation for functional differentiation to assure best use of resources. That local communities can be made to take responsibility for their economic future resonates with contemporary thinking about shared responsibility in development efforts. Essentially local government's role in the process of local development is neither trivial nor impartial. Local development draws on a range of competencies and dictates a new policy and organisational outlook in local government.

\section{Policy Learning and Response in Trinidad \& Tobago \& Jamaica}

Arguably a definitive model of local development is yet to be articulated in the Commonwealth Caribbean but policy learning about the value of local government to the process is evident. Perhaps on account of strong pressure on governments in the region to establish and maintain cohesive systems of subnational governmental frameworks to which the responsibility for local development is to be delegated. An emphasis on an elaborate role for local government in local development is consequential to achieving the goal of democratic decentralization which underpins the governance agenda.

The African Caribbean Pacific Local Government Platform (ACPLGP 2005) ${ }^{2}$ notes the comparative advantage of a developmental role for local government, which inter alia, are:

\footnotetext{
${ }^{2}$ ACPLGP is a representative structure established in May 2001 to defend the interests of local governments in ACP-EU cooperation. It supports the operationalisation of the Cotonou Agreement.
} 
- better understanding of local needs and priorities (as a result of proximity); scope for participatory approaches to development;

- new opportunities for empowering poor and marginalised groups;

- enhanced legitimacy of local government (and national) through increased accountability and transparency in decision-making;

- enhanced spatial coherence of development and poverty reduction efforts (in the framework of overall local development strategies); and

- contribution to peaceful settlement of local conflicts (p.4).

Local government reform policies in the Caribbean have designated the subnational level a separate sphere of socio-economic interaction for the pursuit of developmental objectives. Admittedly, implementation is slow on account of the political cost and benefits that such a policy portends of radical shifts in the decisional power and material resources from one group of actors to another, whether as individuals or organisations.

The subnational level will accrue greater socio-political capital at the expense of the centre. Perhaps this might explain the variance between stout defence of the developmental value of local government and the fact that strategies to realize this goal lag behind. Local government's development orientation is explored in greater depth in the following subsections based on Trinidad and Tobago and Jamaica's experience with reform. For a more comprehensive analysis of the policies see Schoburgh (2006, 2007, 2009).

\section{Trinidad and Tobago}

The Republic of Trinidad and Tobago's Municipal Corporations Act 21 of 1990 and subsequent amendments have resulted in a restructured system of local government into nine regional corporations, three boroughs and two cities (see Table 1). The new structures respond to three main local problems: unevenness in economic growth and development of jurisdictions; blurring of service delivery boundaries due to spill-over of economic activities from burgeoning growth centres; and urbanization with unique service delivery demands. All regions have been granted corporate municipal status to enable the businessisation of the organisations.

Regions are significant to the developmental role envisaged for local government as they are larger geographic spaces than the former county councils and are organised around attributes that are expected to form the base of the economic activity of the local authority. Regionalization is Trinidad and Tobago's strategy for transforming local government. A regional framework is driven by the presumption of greater economies of scale for local 
government in its facilitation of local development and the propulsive nature of the industries that would emerge around those natural endowments that would 'trickle-down'. A communitarian dimension though understated is present in the participation of Citizens' Bureaux that provide the 'tacit knowledge' that is required to ensure greater equity in the distribution of growth.

The Draft White Paper on Local Government Reform 2009 links the reform programme to the realisation of 'developed country status' by 2020. It states:

The charge of the Local Government System in the Vision 2020 National Strategic Plan is to contribute to national development by focusing on regional development and the creation of sustainable communities (RoT\&T 2009: 1).

Essentially Trinidad and Tobago's local government reform policy tends towards amalgamation as the strategic direction in local development.

\section{Jamaica}

Jamaica’s Ministry Paper 8/1993 is also explicit in its intent to reengineer local government as seen in the following statement:

The government perceives both local government and community development as being complementary processes by means of which it can achieve its focal objective of empowering citizens to enjoy greater self-management over their affairs and take initiatives towards, and responsibility for, determining and solving their own problems (p.3).

The policy specifies among its objectives a change in the focal role of local authorities from service delivery as an arms' length agency of central government to "one of providing leadership and a coordinating framework for the collective efforts of the people of their respective parishes towards local development.”

However, in Jamaica a communitarian approach to local development relies on social capital as the primary stimulus evidenced in the establishment of a federated participatory mechanism through which to channel the creative energies of local actors and at the bottom of which are Community Development Committees (CDCs) and at the top, Parish Development Committees (PDCs). Ministry Paper 7/03 envisions that PDCs will "promote local development through partnership of local authorities with other state agencies, the private sector, civil society groups as well as national utility service providers” (pp. 6-7). The expectation is for PDCs to co-produce long-term strategic plans for their respective parishes in which are outlined unambiguous strategies for enhancing local business competiveness which will spur economic development and create employment opportunities (Ibid p. 7). 
Jamaica's local government reform programme, like Trinidad and Tobago's responds to the rapid transformation in the socio-economic profile of local government jurisdictions, brought on by an unprecedented growth in secondary cities and towns that challenge the traditional economic dominance of capital cities and towns. These new and emerging centres of economic activity have been designated Development Areas defined as "localities that exhibit great potential for economic take-off and where social and economic activities cause spillover across the functional areas of local administrative units” (Schoburgh 2007: 169) (see Table 2).

Seventy two development areas have been identified but policy discussions are mostly about effective municipal management arrangement for these discrete urban and rural spaces rather than whether to aim at local integration or local sectoral specialization of these subeconomies. Amendment of the Parish Councils Act to facilitate the creation of municipal corporations, town and area councils and business and special improvement districts (BIDs and SIDs) are options being considered. Already the Municipalities Act of 2003 which established the Municipality of Portmore signals that fragmentation of local government structures is the strategic direction in the quest for local development.

\section{Policy Outputs or Outcomes?}

Despite the debates in both Trinidad and Tobago and Jamaica, local development still remains at the stage of policy dialogue with the most obvious output being demarcation of spatial boundaries within which the process will be managed (see Tables 1 and 3). The model of local development is also shrouded in mystery even with an orientation towards the development-from-below paradigm.

One explanation is that reform has still not identified the 'missing link' in the normative arrangements that are necessary for local development and to which the concepts of 'learning regions and innovative milieus' may be applied. In the absence of these normative arrangements local development becomes unsustainable, particularly in environments where there is a history of integration of local economies into national frameworks, and where civil society activism, a critical ingredient, morphing into political movements that are sometimes co-opted by the centre (central government).

From the newly articulated development plans of both countries one may discern a decisive shift at the macro level from a purely statist or market driven model of development to a 'third path' that incorporates the triad of the state, business and civil sectors, which reflects for the most part the development agenda of the international donor community. 
At the local level this third path manifests in a hybrid model of local development. Hybridized models tell many stories: While a broader normative governance framework may serve as a reference point for economic and political action at central and local levels it does not guarantee congruence in policy outputs. Indeed the triadic relationship at the subnational level in the Caribbean paints a different picture. The extent to which the episodic nature and slow pace of local government reform has captured the interest and imagination of the local private (business) sector is still in question: A point illustrated by the number of PDCs in Jamaica that have failed to achieve their functional mandate due to high incidence of atrophy among its membership.

The Manchester PDC has been the one exception, managing to formulate and publish a strategic plan for the parish, the first of its kind in the Caribbean, with the help of the Canadian International Development Agency (CIDA). The Manchester PDC seemed to have been able to overcome what appears to be a tenuous working relationship between PDCs and local authorities in which there are allegations of power struggle at the individual and organisational levels, partisanship and unethical practices. In the mix are questions about the capacity of local government to forge the requisite synergies among actors. The state's central administrative apparatus continues to be a strong contender in development while local authorities remain tethered to the centre weakening their capacity to innovate in response to theoretical trends in development and local environmental impulses.

Policy reversal is also a feature of reform, illustrated in the pronouncement by the political administration in Jamaica in 2007 that local government would be given greater autonomy. Apportioning a specific percentage of the GDP to this level of government was seen as the best way to delink it from the centre. The most salutary action taken towards this new direction was the downgrade of the Ministry of Local Government to a Department of Local Government. In 2011 a new political administration reverted the Department of Local Government to a ministry with questions being raised about the status of local government. Obviously much is left to be sorted out prior to a specific focus on a developmental local government.

\section{A New Local Development Agenda: Conceptualising the Hybrid Model}

Drawing on the cases of Trinidad and Tobago and Jamaica's local government reform policies, this paper develops the concepts of a hybrid model of local development. This model illustrated in Diagram 1 subsumes neoclassical economic view of community interests as driven by economic utility under a governance paradigm that promotes a multi- 
stakeholder framework based on norms of cooperation, collaboration and partnerships. As Diagram 1 shows, amalgamation through regions is Trinidad and Tobago's strategy for shoring up economic capital; while fragmentation through community management systems assures social capital formation in Jamaica. Economic and social capital thus represent alternative paths to achieving the same goal.

Diagram 1: Modelling approaches to local economic development, Caribbean Trinidad and Tobago Jamaica

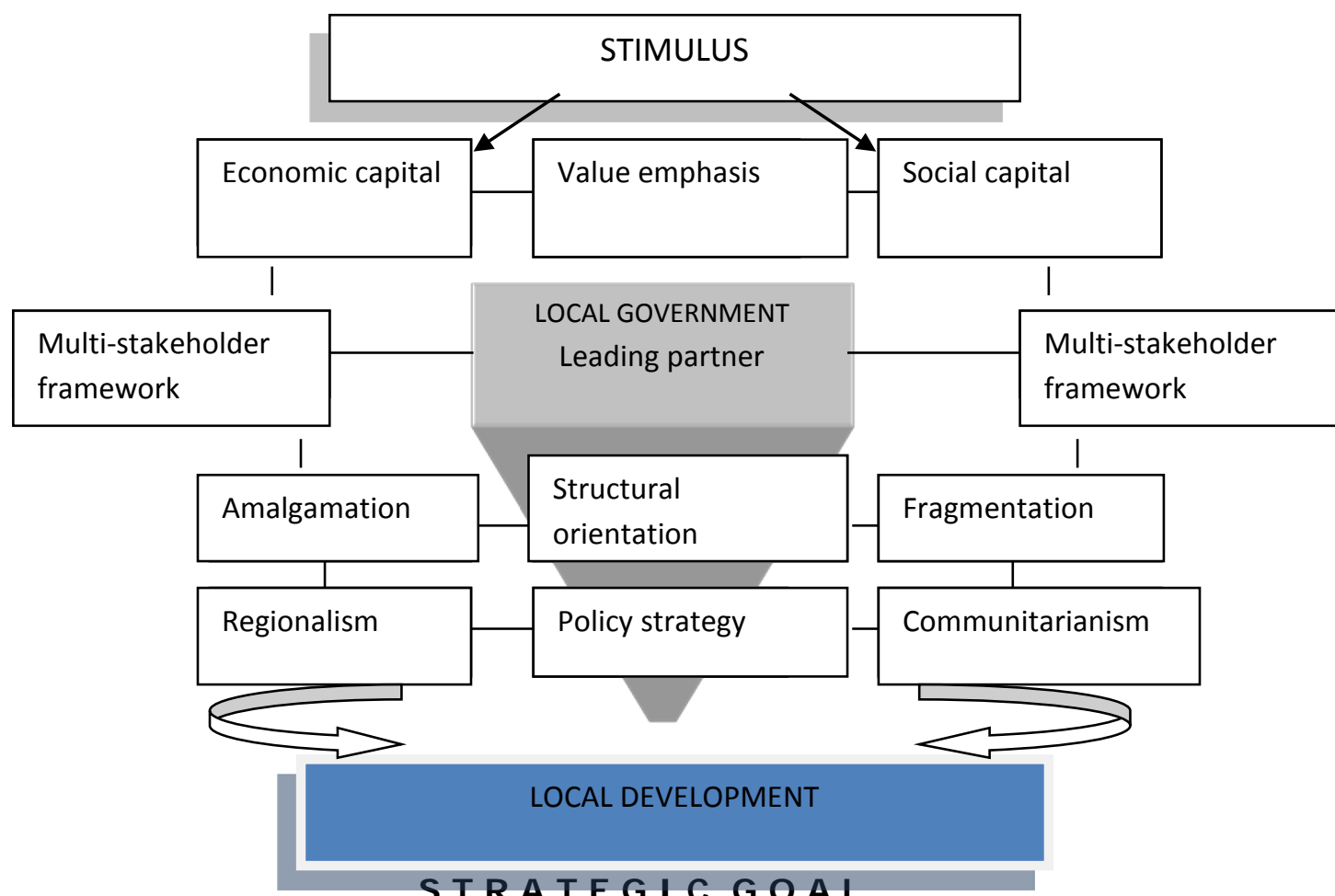

STR A TE G I C GOAL

On the economic side the model departs from the normative private sector-led development strategy and instead assigns a leading role to local government. On the political side it departs from the view that the relationship among the actors involved in the local development process is based on equality. Rather, the model echoes Skocpol's institutional view of development (Skopol 1995), arguing that businesses and civil society groups thrive to the extent that the state actively encourages them (cited in Woolcock and Narayan 2000:234). This view requires a strong local government, working in partnership with the other actors to identify complementarities and forge partnerships. Here politics and economics make easy bedfellows in both countries. The contradiction in the case of Jamaica in operationalising the model, is that the core value of empowered communities that underpins communitarianism is in contradiction to a strong local government. Nevertheless, local government is expected to facilitate the growth of the entrepreneurial spirit and creative energies required for local development. 


\section{Core propositions of the hybrid model}

Despite the potential of a hybrid model, there still exists a high level of reticence in the Caribbean with respect to activation of a new agenda in local development. Issues such as gender equality, risks and opportunities of the informal economy, and the institutional and organisational requirements for managing the 'local commons' must populate the development trajectory. In these socio-economic variables are strategic opportunities for social transformation but they also pose serious threats to the new local order. The paper tackles these issues by setting out three propositions that are essential if the dominance of local government in local development as envisaged in the hybrid model is to be effective.

\section{(En)gendering development}

P1: Mainstreaming gender in local government policy is the only route to assuring a sustainable participatory ethos and by extension sustainable local development.

There is general consensus in contemporary development discourses that sustainable development is predicated on strong democratic institutions which in part explains the renewed interest in local government both as a site for democratic renewal and for its catalytic role in social and economic development. Provided it has the autonomy, authority and resources, local government can enable political devolution which creates the formallegal framework in which communities are empowered to exert their influence on local decision-making (Cheema and Rondinelli (2007). But the democratic value of local government is often in question, which has evoked the question raised elsewhere (Schoburgh 2010) of whether local political institutions in the Caribbean are structured in a manner that permit the development of natural incentives for responsiveness, accountability and representativeness? The latter are the mediating concepts underlying the principles of popular control and political equality, the fundamental pillars on which democratic institutions rest (Ibid).

It is uncertain as to the extent to which local governments in the Commonwealth Caribbean stand up to the scrutiny of popular control or substantiate fulsomely the principle of political equality which attaches to two criteria: “(a) each vote is of equal value irrespective of location or the voter's preference for a particular political party; and (b) each individual regardless of social group status has equal opportunity to stand for public office making the electoral process socially representative” (Ibid). Though not stated definitively, the issue of gender and the situation of women's political participation come to the fore.

Progress has been made in women's political participation in the region but there are several paradoxes. First the Commonwealth Caribbean on a whole has not attained the $30 \%$ quota 
average that countries have committed to ${ }^{3}$ suggesting the unevenness of women's political participation. Moreover, in comparison to their Latin American counterparts women struggle to attain executive and legislative positions at the national level, although are more likely to gain access to the legislative than the executive at the local level. It was found that in 2010 women comprised $21 \%$ of councillors but merely $7 \%$ of mayors in Latin America and the Caribbean (LAC) (see e.g. Htun and Piscopo 2010). Figueroa and Mortley's (2009 c.p) study of Jamaica revealed a tendency for women to achieve higher levels of participation in the administrative as opposed to the political sphere, acting as indoor agents for the political machinery rather than entering representational politics. ${ }^{4}$ They also point out that although women's participation in representational politics tends to be slightly higher in local government than in central government, this has not approached equality and is low in comparison to other countries. Figueroa and Mortley (2009 c.p) provide a forecast ${ }^{5}$ which suggests that women's political participation in Jamaica in 2017 will be below 15\% at the national level and 25\% at the local level (see Figure 1).

Figure 1: Percentage of Female Representation Local and Central Government, Jamaica

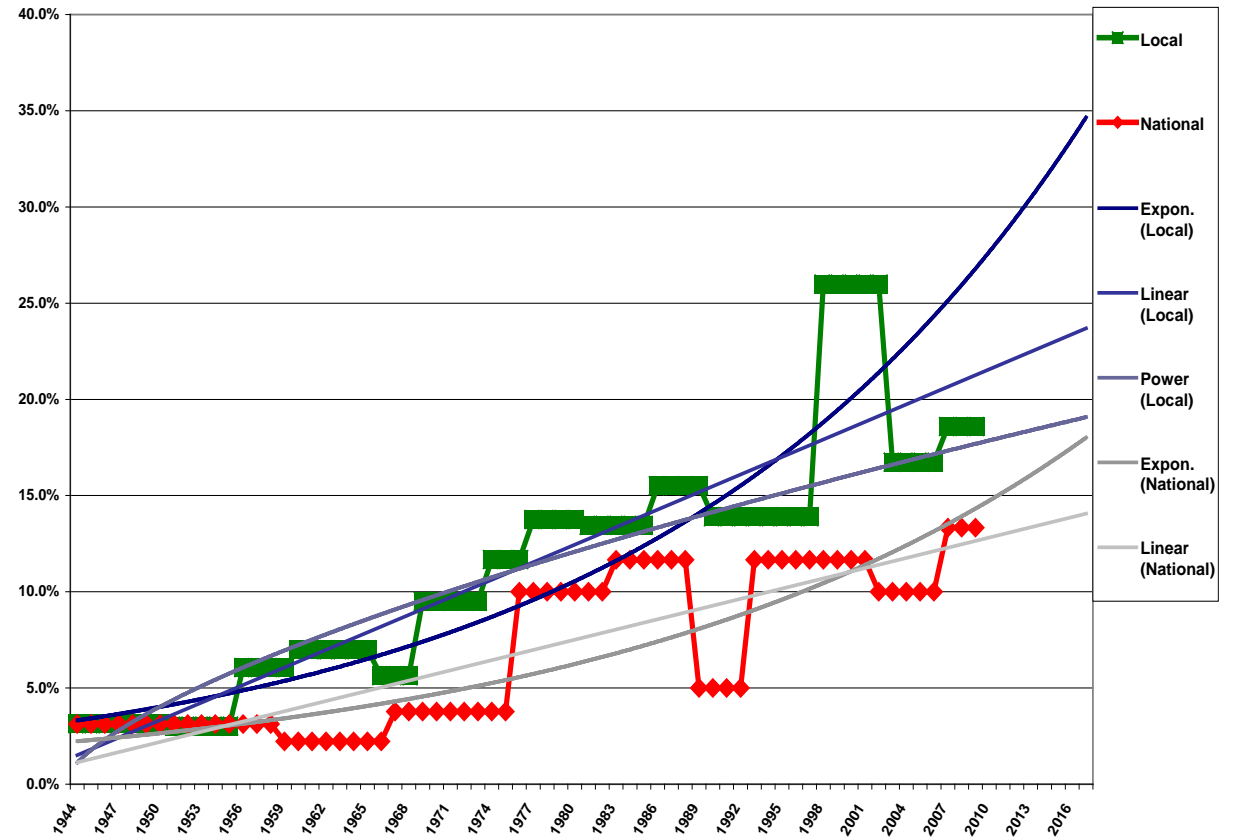

Source: Figueroa and Mortley, 2009

\footnotetext{
${ }^{3}$ At the 1997 Commonwealth Heads of Government Meeting a target of 30\% women in decisionmaking in the political, public and private sectors by 2005 was endorsed as the benchmark for greater gender parity in decision-making in the Caribbean.

${ }_{4}^{4}$ The Human Development Report 2010 argues that "women have traditionally been disadvantaged in the political arena at all levels of government” (p. 91) although the global average of the proportion of women in political leadership still stands at $16 \%$.

${ }^{5}$ Figueroa and Mortley acknowledge the absence of an in-depth study of the party structures that would support more confident predictions about the future of women representation in politics, and derived results from simply fitting trends line to existing data. Using an exponential projection, they note a more optimistic picture with women's participation in local government rising above the $30 \%$ target but remaining below $20 \%$ at the national.
} 
The evidence is clear: Not only is the principle of political equality undermined in local government, implicitly local developmental goals rest on a flawed foundation.

The critical point is that if local government is to assume a developmental role, it is essential that local leaders recognise the centrality of human capital formation to the process of local development. Moreover the alternative development models and empowerment strategies require a shift in organisational focus from the standard tasks of infrastructure development to human resource development as the basis for a holistic approach to local development and as a way of unearthing the creative talents and energies of citizens within their jurisdictions. The latter are a priori to increased productivity at the local level and by extension the transformation of social values into sustainable economic values. Local government is thus the arena in which to resolve the outstanding matter of gender parity not merely for the imbalances that characterize political and administrative leadership but for their potentially negative impact on [community] empowerment, as well as the strategic goal of socioeconomic transformation as acknowledged in the Human Development Report 2010 and the Millennium Development Goals (MDGs) - Goal \#3.

The National Advisory Council (NAC) on local government reform in Jamaica is unequivocal about the sine qua non of gender equity and the empowerment of women noting that they constitute more than $50 \%$ of the population; have particular needs and interests that are elemental to the ethos of local services; are already the principal actors in community management whether through formal or informal networks and importantly are linked with the pursuit of the 'common good' (NAC Report 2009: 9). Gender equity is linked directly to good quality social capital as noted in the NAC's prefatory comments that:

...on the guaranteed empowerment of women rests the expected desired outcomes of the sort of social transformation which will socialize the youth around to values of tolerance one to another, mutual respect in relating to both leaders and peer groups, collaborative and cooperative endeavours starting with family extending to yard, village, community parish and nation (NAC Report 2009: 5).

Essentially local development is inextricably tied to issues of gender, which demands deliberate and decisive action in identifying those factors that are strategic to economic transformation which leads to the second proposition.

\section{Transforming informal citizenship into economic citizenship}

P2: Local development involves: (a) the integration of peripheral groups/economies into mainstream socio-economic development processes; and (b) an understanding of the social relations of the informal economy as a basis for transforming informal citizenship into economic citizenship. 
The concept of 'growth centres' presents another opportunity for an examination of what is required of local government in its developmental role. 'Growth centres' are portrayed as incubators of economic take-off but represent a paradox for local development in that more often than not, rather than outcomes of rational policy making, they are the consequences of spontaneous economic activities of private individuals whose single purpose is to maintain their household income. Many of these economic activities are not integrated into formal economic structures as a result but remains in their natural state outside the pale of government regulation creating a type of parallel economy.

Growth centres sometimes emerge as a source of consternation for local governments for two reasons: (a) they create a high degree of economic spillover that blurs service boundaries and causes jurisdictional overlaps as they are frequently associated with densely population areas, and (b) they utilize local services without bearing the true economic cost. The socioeconomic linkages from this economic sub-sphere have challenged the capacity of local government to meet local needs efficiently and effectively and have propelled restructuring reforms, as exemplified in the case of Jamaica's municipal management systems to respond to these issues via the Development Areas and Business District concepts; regional corporations is the answer for Trinidad and Tobago.

Strategies to spur local economic development must thus confront the phenomenon of the informal economy which is being suggested here is a dimension of "growth centres". The concept describes the whole range of informality - both enterprise and employment relations - manifesting in industrialized, transition and developing economies and which is representative of production that occurs outside of visible, formal organisations, subjected to the laws and policies of the state (Harrod 1987:122; Portes and Haller 2005; Tokman and Klein 1996; Witter and Anderson 1991 ; Witter and Kirton, 1990)). An Inter-American Development Bank (IDB) 2004 study characterized the informal economy as:

....an atomic configuration of economic units that compete individually with each other, in the absence of productive cooperative links and linkages with large firms (Ibid: 165).

The trouble is that the informal economy, though within the oversight of local governments in the region, has turned out to be a case of missed economic opportunity. Notwithstanding that its economic value has been identified in national economic discourses, very little attempt is made in local policy, outside of provisional regulatory activities, to understand its constitutive dimensions in order to either shape discourses or devise strategies to deal with it. For instance, explanations have shifted from emphasizing the logic of economic survivalism, 
though still considered critical in the development of this phenomenon, to the logic of decentralization in the context of a liberalized macro economic framework (Tokman 2001).

As an instrument of decentralizing reforms there exists a proximal relationship between local government activities and the informal economy which renders the latter an imperative of local policy analysis. The "wait-and-see" stance adopted by local government officials against a perception that the informal economy will simply disappear with regulation, belies its complex nature. As Tokman (2001: 50) argues "informal activities are not caused by regulatory inadequacies, but rather by the failure of the economic system to create enough productive employment.” Herein lays the first clue to the direction that policy-making in local government ought to be reoriented.

Part of the complexity of the informal economy lies in its far-reaching social effects, the most recent exposition of which is found in Schoburgh's (2007) seminal article: Informal economy and informal citizenship: Exploring causation and connectivity in socio-politico shifts in Jamaica that introduces the concept of informal citizenship to the debate around the social relations of the informal economy. Schoburgh (2007a) characterized these social relations thus:

The informal economy provides participating agents/individuals with a first-hand experience of the inability of the formal institutions to meet their needs and guarantee those benefits to which they are entitled through their social membership and participation in the wider political community. Through this welfare function the informal economy facilitates a psychological retreat from the wider society by those who operate within it and the creation of a 'social world' in which the actions of participating agents are subjectively justified (9).

Out of the socio-economic experience of the informal economy evolves an informal citizenself with a particular socio-political affect (whether as an individual or group) that is instrumental in nature and which guides behaviour towards self-interested ends (Ibid). This informal-citizen-self undermines traditional notions of citizenship giving rise to an informal citizenship which for Schoburgh (2007a):

... is a status acquired through an individual's membership in a social substructure/sub-group with which he/she identifies as the legitimate collective/context in which to pursue those claims normally associated with and attached to formal citizenship status. Informal citizenship resides in that realm of formal citizenship status where particularistic needs (be they political and civil, economic, or sociocultural) are either un-met or under-met and where a subordinated social system assumes responsibility for meeting them (p. 11).

Informal citizenship status destroys cooperative relationships as well as good social capital, and a stance of neglect on the part of local government has to change as it must balance the economic and social aspects of local development by integrating under-served publics into 
local development policy processes. Employment creation, poverty reduction, and women's and community empowerment are cross-cutting issues that find sustenance in the informal economy.

Local government in its role as enabler of local development and in light of its implied function in substantiating citizenship, must be made to see that the informal economy represents an alternative development strategy for two fundamental reasons: (a) its potential development impact - it is an economic opportunity zone; and (b) the implications it has for social membership of a political community - it is a source of informal citizenship. These issues are linked to the final proposition.

P3: Managing the 'local commons': The principal role of local government in local development is managing the commons which translates into developing the capabilities to regulate the use of community assets and forging and sustaining synergistic relationships among actors.

If there is a single lesson to be taken from the theories reviewed earlier it is that irrespective of the model of local development adopted the repositioning of local government towards a developmental role rests on three criteria: knowledge about a locality's resource base; strategy(ies) to transform latent and emergent resources into economic values for development, and capacity(ies) to ensure that a locality's competitive advantage is sustained over a longer term. This inference is complemented by Blakely and Bradshaw's (2002: 341) observation that "economic development is an institution-building process." In this sense local government as the enabler must forge and sustain synergistic relationships among local actors which in turn will evolve new norms and practices towards the achievement of social goals, recognising that such a process can hardly be left to occur by accident (see, e.g. Hardin 1968; Ostrom et al 1999).

'Commons' in this analysis is a metaphor for the range of interactions that links actors (policy makers and citizens) in the local development 'enterprise'. When the concept of the 'commons' is substituted with the local space in which social goals are pursued the application is clear: development benefits and costs accrue to all, not at the same time nor in the same quantum and as a result produces a contested terrain creating a dilemma for local development policy as local actors follow their own short term interests (Ostrom et al Ibid.) rather than pursue long-term collective goals. The presumption of self-interested behaviour does not mean that the 'commons' is devoid of cooperative norms. Neither should an assumption be made that because the policy approach to local development involves cooperation among a range of actors (public, private and civil) that these norms will evolve 
naturally. They may or may not, depending on the development issues, strategies and goals and the distributional effects in relation to costs and benefits. Local development requires a neutral arbiter to mediate the contending and sometimes conflicting interests and positions. Implications for the internal capacity (i.e. institutional arrangements and organisational capabilities) are obvious. Managing the 'local commons' is therefore a process of institutional design in which the 'rules of the game' are 'devised deliberately'.

Fortunately the policy approach to local development in the Commonwealth Caribbean has demonstrated that partnerships and collaborative arrangements constitute the new 'rules of the game' but negotiation and consensus-building, monitoring and enforcement activities remain to be sorted out. In fact the multi-stakeholder framework of the hybrid model requires that local government ascertain the nature of the vested interests that people and organisations have in an area's economic development as a basis for managing partnerships and collaborations. The concept of covenanting has been explored elsewhere (Schoburgh 2009). To do so hinges on requisite capacity on which issue the literature provides a direction, suggesting two types of institutional endowments that are necessary for the assumption of an economic developmental role: authority - the legitimate power to act on behalf of local actors; and resources - the technical, material and informational stocks at the disposal of the organisation. These are linked to specific organisational behaviour and outlook (Blakely and Bradshaw 2002) shown in Table 4 and are self-explanatory.

Table 4: A Profile of Local Development Organisations

\begin{tabular}{|ll|}
\hline ROMIPONENTS & \multicolumn{1}{c|}{ DESCRIPTION } \\
Information provision & $\begin{array}{l}\text { Generation of policy relevant information; needs } \\
\text { assessment; establishing causation } \\
\text { Identification and articulation of policy issues/problems, } \\
\text { developmental goals/alternatives and targets }\end{array}$ \\
Marketing & $\begin{array}{l}\text { Promotion of development attributes (of locale) and } \\
\text { strategies }\end{array}$ \\
Coordination & $\begin{array}{l}\text { Synchronization of local interests for collective goals; } \\
\text { balancing efficiency and equity }\end{array}$ \\
Learning and & $\begin{array}{l}\text { Development of technical capacity for innovation; } \\
\text { utilization of feedback instruments; infusion and } \\
\text { deployment of new information and communication } \\
\text { technologies (ICTs) to support existing technologies }\end{array}$ \\
Leadership & $\begin{array}{l}\text { Strong and competent leadership with progressive } \\
\text { worldview at individual and organisational levels and } \\
\text { straddling political and administrative dimensions }\end{array}$ \\
\hline Author's elaboration of Blakely and Bradshaw's (2002) ideas. \\
CJLG December 2011 - Jul 2012
\end{tabular}


Applying the concepts of 'learning regions' and 'innovative milieus' it may be inferred that the contemporary local development 'commons' requires that local government develops a 'technical culture' - described as "a way to develop, store and disseminate knowledge, technical know-how, norms and values - linked to a certain type of economic activity" (Plummer and Taylor 2001: 226). The evidence in the Caribbean suggests new roles, new functions and new outlook for individuals and organisations.

\section{Analysis and Conclusion}

Theoretical explanations of local development and the models that are attached do not have universal application. Nor are they expected to. Yet they offer useful insights into understanding the role that local government and communities are expected to play in facilitating the local development process. The 'leading-laggard' or 'hierarchy of settlements' concepts even with their economic determinism illustrate that there is an external dimension to the pursuit of local development irrespective of the source of the impetus for change. That is, local policy must account for the various types of linkages as well as the manner in which the locality is integrated into the national and even international economies. The idea of 'growth centres' directs attention to a fundamental policy action, that is, identification of locational attributes of a community and ascertaining their relative value to form a promotional package in order to attract the necessary investments. With advancements in technology that have spawned different and more unpredictable behaviours in investors as exemplified in the growth of e-commerce and 'foot-loose' industries, reliance on natural physical endowments and close proximity to markets as primary pull factors for development may not be adequate bases on which to plan. Increasingly natural resources have to be complemented by other types that are socio-cultural and institutional in nature: To which issues 'learning regions' and 'innovative milieus’ point.

If there is one inference that theories of local development offer, it is that location is more than the physical space and thus suggests the adoption of a pragmatic approach to local development. As Blair (1995:15) observes "local economic development is part of a larger process of community development.” Also following Coffey and Polese’s (1984), local development is a process "in which 'local' factors - the local spirit of entrepreneurship, local firms, or local financial institutions - constitute the principal bases” for local economic growth - taken to mean an increase in employment rates, expansion in the number and size of businesses, and increase in per capita incomes, hardly means the preclusion of a broader process of development that takes into account the 'softer' (social relational) side of economics. 
The second inference is that economic development is a critical dimension of local development. And perhaps a false dichotomy is created between local development and LED in the context of local government. For as Beauregard (1993) observes there are 'fictions' associated with the label economic. LED is a process in which "individuals and organisations engage in production, distribution and consumption of goods and services” at the local level (p. 269). But there is difficulty in delineating between economic and non-economic realms in policy practice as LED may also be interpreted as "the enhancement of institutions that make capital investment possible and successful” (Ibid 271) among which are financial institutions, but also education and training entities, legal structures, social networks of entrepreneurs and inventors, mutual support groups (informal sector) and notably governments (Ibid). The latter interpretation resonates with the economic developmental role of local government. The question that remains is: Which should be the focus - local development or LED? This might be the source of the ambiguity observed in the model of development hypothesized and hence the hybrid model attempts to be all things to all people.

Local development is increasingly seen in consonance with local government. At this stage of local government reform in the Caribbean there is sufficient evidence of an attempt to reformulate the critical components of the policy cycle to reflect relevant theoretical norms and respond to urgent empirical trends. While location remains constant it is modified by qualitative aspects such as empowered communities and citizens linked by networks and partnerships to indicate that policy has arrived at a firm position on what the critical ingredients for determining competitiveness of a socio-economic and cultural space.

Local development is implicitly recognised as having a broader connotation and is not merely about place but about the people that occupy that space, plus the interactions that form the bases of institutions in that space. As the partner accorded the status of primus inter pares in local development, local government has the task of ensuring that models and strategies of local development are in synchrony with the new requirements of local development. Local government must therefore confront the issues of gender and the informal economy frontally in order to maximize human and natural resources in the process of wealth creation. In these factors reside unconventional policy tools, capacities and sources of new forms of wealth. In their absence the ideas and strategies of local development are 'dead on arrival.' 


\section{Acknowledgements}

I am grateful for the comments of the reviewers that have helped in strengthening the analysis. However I take full responsibility for any other shortcomings in the paper.

\section{References}

Ayeni, Victor, 2004. Preface. In Local democracy and good governance in the Caribbean. Report of the Regional Symposium held in Montego Bay, Jamaica, April 2004, London. p. ix.

Cheema, G. Shabbir and Dennis A. Rondinelli. 2007. Decentralizing Governance: Emerging Concepts and Practices. Washington DC: Brookings Institution Press.

Clague, Christopher. (Ed) 1997. Institutions and Economic Development: Growth and Governance in Less-Developed and Post-Socialist Countries. The Johns Hopkins University Press.

Carr, James. 1999. Community, Capital and Markets: A New paradigm for Community Reinvestment. The NeighborWorks. (Summer) pp. 1-4.

Coffey, William J. and Mario Polese. 1984. The Concept of Local Development: A Stages Model of Endogenous Regional Growth. Twenty-Third European Congress of the Regional Science Association. Volume 55. pp. 1-12.

CLGF (Commonwealth Local Government Forum) 2011a. Trinidad \& Tobago - Country profile. http://www.clgf.org.uk/userfiles/1/Feb2008_Country_Files/TRINIDAD_TOBAGO.pdf. Accessed February 7, 2011.

CLGF (Commonwealth Local Government Forum Country Profile). 2011b. Jamaica - Country profile, http://www.clgf.org.uk/userfiles/1/Feb2008_Country_Files/JAMAICA.pdf.

Accessed February 7, 2011.

CS (Commonwealth Secretariat). 2004. Local democracy and good governance in the Caribbean. Report of the Regional Symposium held in Montego Bay, Jamaica, April 2004, London.

Duncan, Neville, 2004. Local Government and Governance for the Twenty-first Century: The Anglophone Caribbean. In Local democracy and good governance in the Caribbean. Report of the Regional Symposium held in Montego Bay, Jamaica, April 2004, London. pp. 43-66.

Figueroa, M and Natasha Mortley. Progress towards Gender Equality in Political Leadership in the Caribbean: The Case of Local versus Central Government in Jamaica, 1944-2007. Paper presented at the Conference on Local Governance and Inter Governmental Relations in the Caribbean: Examining the Past, Assessing the Present and Predicting the Future, 8-9 January 2009, UWI Mona.

Friedmann, John and Clyde Weaver. 1979. Territory and function: the revolution of regional planning. Berkley: University of California Press.

Fujita, Nanako. 2007. Myrdal's Theory of Cumulative Causation. Evolutionary and Institutional Economics Review. Volume 3. pp. 275-283.

Harding, Garrett. 1968. The Tragedy of the Commons. Science. Volume 162.

Harrod, J. (1987) Power, Production and the Unprotected Worker. New York: Columbia University Press.

Howland, M. 1993. Applying Theory to Practice in Rural Economies. In eds. Robert Bingham and Robert Mier. Theories of Local Economic Development Perspectives From Across the Disciplines. London: SAGE Publications. Pp. 61-79

IDB, 2004. Informal Sector Study for Jamaica, Preliminary Report, September 2004. Study conducted by Group of Analysis for Development (GRADE) for Inter-American Development Bank.

J DoLG (Jamaica, Department of Local Government). 2009 Final Report of the National Advisory Council on Local Government Reform, 2009.

J MoLG (Jamaica, Ministry of Local Government). 1993. Ministry Paper 8 of 1993.

J MoLG (Jamaica, Ministry of Local Government). 2003. Ministry Paper 7 of 2003.

Kuznets, Simon. 1965. Towards a theory of economic growth. New York: Norton. 
Kuznets, Simon. 1966. Modern Economic Growth. New Haven, New York: Yale University Press.

Malizia, Emil E. and Edward J. Feser. 1999. Understanding Local Economic Development. New Jersey: New Brunswick: Center for Urban Policy Research.

Malmberg, Anders; Orjan Solvell and Ivo Zander. 1996. Spatial Clustering, Local Accumulation of Knowledge and Firm Competitiveness. Human Geography. Volume 78 number 2. pp. 85-97.

Myrdal, Gunnar. 1957. Economic Theory and Underdeveloped regions. London: Duckworth.

Ostrom, E. 1990. Governing the Commons: The Evolution of Institutions for Collective Action. Cambridge: Cambridge University Press.

Ostrom, E 1994. Institutional Analysis, Design Principles and Threats to Sustainable Community Governance and Management of Commons. In R. S. Pomeroy. ed. Community management and common property of coastal fisheries in Asia and the Pacific: concepts, methods and experiences. International Centre for Living Aquatic Resources Management (ICLARM). pp 34-50.

Ostrom, E. et al. 1999. Revisiting the Commons: Local Lessons, Global Challenges. Science. volume 284. pp. 278-282.

Ostrom, E. 2005. Understanding Institutional Diversity. Princeton University Press.

Perroux, Francois. 1950. Economic Space: Theory and Applications. The Quarterly Journal of Economics. Volume 64, number 1 (February), pp. 89-104.

Plummer, Paul and Mike Taylor. 2001. Theories of local economic growth (part 1): concepts, models, and measurement. Environment and Planning A. volume 33. pp. 219-236.

Porter, Michael E. 1990. The competitive advantage of nations. New York: Free Press.

Porter, Michael E 1995. The Competitive Advantage. Harvard Business Review. (May-June) Reprint number 95310. pp.55-71.

Porter, Michael E 1998. The Adam Smith Address: Location, Clusters, and the "New" Microeconomics of Competition. National Business Association for Business Economics. Webbed at: http://www.econ.nyu.edu/dept/courses/niemira/980107.pdf. Accessed January 31, 2011.

Portes, A and Haller, W. (2005) “The Informal Economy” in Neil J. Smelser and Richard Swedberg. eds. The Handbook of Economic Sociology 2nd Edn. Princeton: Princeton University Press, pp. 403-425.

Schoburgh, E. D. 2006. Local government reform: The prospects for community empowerment in Jamaica. Mona, Jamaica: SALISES.

Schoburgh, E. D. 2007. Local Government Reform in Jamaica and Trinidad: A Policy Dilemma. Public Administration and Development. 27. pp. 159-174.

Schoburgh, Eris. D 2007a. Informal economy and informal citizenship: Exploring causation and connectivity in socio-politico shifts in Jamaica. Caribbean Development Review. Volume 1 (December) pp. 1-16.

Schoburgh, E. D. 2009. Paradigm Shift or Rhetorical Flourish? The ‘New Orthodoxy’ of Local Governance in the Caribbean. Social and Economic Studies 58: 1. pp. 95-124.

Schoburgh, E. D. 2010. Is Subsidiarity the Panacea for Local Government Problems in the Caribbean? Social and Economic Studies 59: 4. pp. 27-66.

Skocpol, Theda. 1995. Protecting Soldiers and Mothers. The Political Origins of Social Policy in the United States. Cambridge, Mass.: Harvard University Press.

Tokman, V. 2001. Integrating the Informal Sector into the Modernization Process. SAIS Review volume XX1 number 1 (Winter-Spring). pp. 45-60.

Tokman, V. and Klein, E. 1993. Informal Sector and Regulations in Ecuador and Jamaica. Technical Paper number 86, Development Centre of the Organisation for Economic Cooperation and Development.

ACPLGP (The African Caribbean Pacific Local Government Platform). 2005. Local government participation in ACP-EC cooperation. An initial assessment and prospective. Final Report, 2005. 
RoT\&T. 2009. The Republic of Trinidad and Tobago. Ministry of Local Government. Draft White Paper on Local Government Reform, 2009.

Witter, M. and Anderson, P. 1991. “The Distribution of the Social Cost of Jamaica’s Structural Adjustment 1977-1989”, University of the West Indies.

Witter, M. and Anderson, P and Kirton, C. 1990. "The Informal Economy in Jamaica: Some Empirical Exercises” Working Paper 36, Institute of Social and Economic Research, University of the West Indies, Mona

Woolcock, M. and Deepa Narayan. 2000. Social Capital: implications for Development Theory, Research, and Policy. World Bank Research Observer. Volume 15 Issue 2. pp. 225-249. 


\section{Appendix 1}

Table 1.Distribution of authorities, Trinidad and Tobago

\begin{tabular}{|c|c|c|c|}
\hline & Municipal corporations & Population & \% rural \\
\hline \multirow[t]{2}{*}{ City } & Port of Spain & 49,031 & 0 \\
\hline & San Fernando & 55,419 & 0 \\
\hline \multirow[t]{3}{*}{ Borough } & Arima & 32,278 & 0 \\
\hline & Chaguanas & 67,433 & 95 \\
\hline & Point Fontin & 19,056 & 90 \\
\hline \multirow[t]{9}{*}{ Region } & $\begin{array}{l}\text { Couva-Talparo- } \\
\text { Tabaquite }\end{array}$ & 162,797 & 95 \\
\hline & Diego Martin & 105,720 & 10 \\
\hline & Mayaro-Rio Claro & 32,143 & 100 \\
\hline & Penal-Debe & 83,609 & 80 \\
\hline & Princes Town & 91,947 & 87 \\
\hline & Sangre Grande & 65,680 & 72 \\
\hline & San Juan-Laventille & 157,295 & 10 \\
\hline & Siparia & 81,917 & 92 \\
\hline & Tunapuna-Piarco & 203,975 & 93 \\
\hline Total & (14) & $1,208,300$ & 60 \\
\hline
\end{tabular}

Source: Commonwealth Local Government Forum Country Profile Website (CLGF 2011a)

Table 2. Local Development Management Structures, Jamaica

\begin{tabular}{|l|c|c|c|}
\hline \multicolumn{1}{|c|}{ Parishes } & $\begin{array}{c}\text { Municipal } \\
\text { Management Areas }\end{array}$ & $\begin{array}{c}\text { Development } \\
\text { Areas }\end{array}$ & Communities \\
\hline Kingston \& St. Andrew & 1 & 13 & 82 \\
\hline St. Thomas & 3 & 3 & 51 \\
\hline Manchester & 3 & 3 & 73 \\
\hline Clarendon & 3 & 6 & 58 \\
\hline St. Elizabeth & 3 & 5 & 69 \\
\hline Westmoreland & 3 & 3 & 41 \\
\hline Hanover & - & 3 & 85 \\
\hline St. James & 1 & 3 & 38 \\
\hline Trelawny & - & 9 & 48 \\
\hline St. Ann & - & 5 & 30 \\
\hline St. Mary & - & 6 & 40 \\
\hline Portland & 3 & 4 & 48 \\
\hline St. Catherine & $1^{\text {a }}$ & 72 & 745 \\
\hline Total & & & \\
\hline
\end{tabular}

a. Portmore Municipality created 2003. 
Table 3. Distribution of local authorities and population, Jamaica

\begin{tabular}{|l|l|l|}
\hline Local authority & Population & \% rural \\
\hline Clarendon & 228,300 & 70.0 \\
\hline Hanover & 67,500 & 91.7 \\
\hline Kingston \& St. Andrew & 716,000 & 11.5 \\
\hline Manchester & 188,800 & 66.2 \\
\hline Portland & 79,400 & 79.2 \\
\hline St. Ann & 164,900 & 75.5 \\
\hline $\begin{array}{l}\text { St. Catherine } \\
\text { Portmore }\end{array}$ & 413,200 & 29.9 \\
\hline St. Elizabeth & & 89.9 \\
\hline Sr. James & 148,600 & 45.8 \\
\hline St. Mary & 180,800 & 79.4 \\
\hline St. Thomas & 112,800 & 74.1 \\
\hline Trelawny & 92,400 & 81.7 \\
\hline Westmoreland & 72,500 & 80.0 \\
\hline Total (14) & 140,600 & 50.4 \\
\hline
\end{tabular}

Source: Commonwealth Local Government Forum Country Profiles Website (CLGF 2011b) 